\title{
Knowledge and Perception on Prevention of Hospital Acquired Infections (HAI) among Health Care Professionals in Tertiary Care Teaching Hospital
}

\author{
Vasantha Priya Jeyasheelan ${ }^{1} \mathbb{D}$, Sumetha Suga Deiva Suga² ${ }^{\mathbb{D}}$, Sindhura \\ Myneni $^{3}$ (D) , Divya Ravikumar ${ }^{3}$ (D) Manuel Raj Kumar ${ }^{4}$ (D) , Poonguzhali \\ Sivagananam $^{1}\left(\mathbb{D}\right.$, Vahithamala Kunasekaran ${ }^{5}$ (D), Pandian Balu ${ }^{1}(\mathbb{D})$, Udayakumari

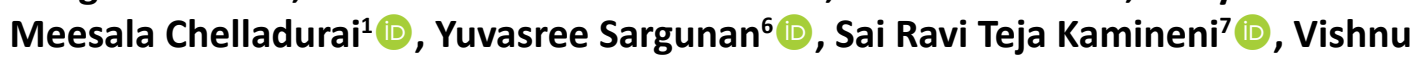 \\ Priya Veeraraghavan $^{8}$ (D) and Surapaneni Krishna Mohan ${ }^{9 *}$ (D)
}

\begin{abstract}
${ }^{1}$ Department of Medical Surgical Nursing, Panimalar College of Nursing, Varadharajapuram, Poonamallee, Chennai - 600 123, Tamil Nadu, India. ${ }^{2}$ Department of Microbiology, Panimalar Medical College Hospital \& Research Institute, Varadharajapuram, Poonamallee, Chennai - 600 123, Tamil Nadu, India. ${ }^{3}$ Department of Obstetrics \& Gynaecology, Panimalar Medical College Hospital \& Research Institute, Varadharajapuram, Poonamallee, Chennai- 600 123, Tamil Nadu, India. ${ }^{4}$ Hospital Infection Control Nurse, Panimalar Medical College Hospital \& Research Institute, Varadharajapuram, Poonamallee, Chennai - 600 123, Tamil Nadu, India. ${ }_{5}^{5}$ Department of Community Health Nursing, Panimalar College of Nursing, Varadharajapuram, Poonamallee, Chennai - 600 123, Tamil Nadu, India. ' Department of Computer Science, Panimalar Institute of Technology, Varadharajapuram, Poonamallee, Chennai - 600 123, Tamil Nadu, India. ${ }^{7}$ Department of Tuberculosis \& Respiratory Diseases, Panimalar Medical College Hospital \& Research Institute, Varadharajapuram, Poonamallee, Chennai - 600 123, Tamil Nadu, India. ${ }^{8}$ Department of Biochemistry, Saveetha Dental College \& Hospital, Saveetha Institute of Medical \& Technical Sciences (SIMATS), Saveetha University, Velappanchavadi, Chennai - 600 077, Tamil Nadu, India. ${ }^{9}$ Department of Biochemistry, Panimalar Medical College Hospital \& Research Institute, Varadharajapuram, Poonamallee, Chennai - 600 123, Tamil Nadu, India.
\end{abstract}

\footnotetext{
*Correspondence: krishnamohan.surapaneni@gmail.com

(Received: May 05, 2020; accepted: June 15, 2020)

Citation: Jeyasheelan VP, Deiva suga SS, Myneni S, et al. Knowledge and Perception on Prevention of Hospital Acquired Infections (HAI) among Health Care Professionals in Tertiary Care Teaching Hospital. J Pure Appl Microbiol. 2020;14(2):1527-1536. doi: 10.22207/JPAM.14.2.51

(c) The Author(s) 2020. Open Access. This article is distributed under the terms of the Creative Commons Attribution 4.0 International License which permits unrestricted use, sharing, distribution, and reproduction in any medium, provided you give appropriate credit to the original author(s) and the source, provide a link to the Creative Commons license, and indicate if changes were made.
} 


\begin{abstract}
Hospital-acquired infections (HAIs) are infections which are absent at the time of admission and would have been acquired after hospitalization. The purpose of the study was to evaluate the knowledge and perception levels on preventing $\mathrm{HAl}$ among health care professionals in tertiary care setup. The semi-structured tool was used for data collection. Out of 367 health care professionals, 262 participants were included in the study. Data were analyzed with descriptive and inferential statistics. The mean level of knowledge and perception score on HAI was $19.58 \pm 2.70$ and $51.97 \pm 5.62$. There was a positive correlation among the level of knowledge with level of perception on the prevention of $\mathrm{HAl}(r=0.16)$ at $p>0.01$. The knowledge and perception level was significantly associated with few demographic variables such as following protocols of hand hygiene,trainings on HAI within last year and functioning infection control department in their institution at $p=0.001$. Health care professionals have adequate knowledge and perception regarding the prevention of HAl. There should be emphasized refreshment and updates on the current trends on the prevention of HAl among the health care professionals through intensive education and conducting training courses.
\end{abstract}

Keywords: Hospital-acquired infections, knowledge, perception, health care professionals

\section{INTRODUCTION}

Hospitals around the world, health workers are playing a major role in treating patients with health-related problems and infections. Hospital-acquired infections (HAIs) are the major challenge across the globe as the HAls markedly influence the quality of health care delivery, mainly by adding burden to the underdeveloped and developing countries ${ }^{1}$. The main mode of transmission of HAls is from patient to patient through health care professionals who did not follow the standard precautions ${ }^{2}$. HAl is not present at the time of hospitalization of the patient but has acquired by the patient within the time frames of 48-72 hours after hospitalization, 3 days after leaving the hospital, 30 days after surgery, or 1 year after the implant ${ }^{2}$.

World Health Organization (WHO) has defined the Hospital-acquired infection (HAI) (or) Nosocomial infection (or) Health care-associated infection, as an infection acquired in a hospital or other health care facility ${ }^{3}$. HAl will lead to create a greater effect on the healthcare economy by attenuating high risk area stay, lengthening the hospital stay, and increasing the chance for the need of invasive procedures. There are many HAls, among them the most common are urinary tract infections (UTI), primary bloodstream infections (BSI), surgical site infections (SSI), and ventilatorassociated pneumonia (VAP) ${ }^{4}$.

Health-care workers and asymptomatic patients who are carrying pathogenic superbugs act as the platform for the spread of such infections to other patients who are seeking medical care. More than seven million HAl cases occur every year ${ }^{5}$. Among 20 people admitted to the hospital, at least one person will be affected by HAl, which leads to more than 90,000 death cases yearly and imposes a thirty million price burden to the community 5 . A study conducted by the WHO in more than 50 hospitals in 14 countries revealed that more than $8.7 \%$ of the patients hospitalized have been infected with hospital-acquired infections ${ }^{6}$.

Retention of knowledge, attitudes and practices can be achieved through continuous education for positive impact on professionals working at all the various levels of the health care system. To reduce the occurrence of nosocomial infections, the need for continuous education and vigorous training must be considered. Therefore, the present research was done to investigate the level of knowledge, perception, and correlation on preventing $\mathrm{HAl}$ and also to find out the association of demographic variables with knowledge and perception on $\mathrm{HAl}$ among the health care workers.

\section{MATERIALS AND METHODS}

The present study was a cross-sectional study conducted in Panimalar Medical College Hospital \& Research Institute, Chennai, Tamilnadu, India. A semi- structured questionnaire framed by the researchers has been used to analyze the knowledge and perception of preventing nosocomial infections among health professionals in tertiary care centers. Those subjects who were 
willing to provide informed consent and also those who are working in the tertiary care hospitals were involved in the study. The questionnaire was given to the study participants for assessing knowledge and perception. The participants filled up the demographic details ( 1 to 11 ) of the questionnaire. Sequentially the next knowledge questionnaire from 12 to 34 (yes or no questions) was filled. After that they have to complete the next perception questionnaire from 35 to 46 , which was measured by using a 5 point Likert scale. In this study for analyzing the findings descriptive statistics have been used. The results of the study were estimated by using mean, standard deviation, and proportions.

\section{Interpretation of the Scores}

To assess the knowledge component, 23 questions were incorporated into the questionnaire assigning one (1) point for correct response and zero for the incorrect response. A cumulative score of $\leq 8$ points was categorized as inadequate knowledge criteria; $\leq 15$ points was considered as moderately adequate knowledge criteria and $\leq 23$ points was considered as adequate knowledge. To assess the attitudes/perceptions 12 questions were incorporated into the survey instrument on a 5-point Likert scale. A score of $\leq 16$ points was considered as negative attitudes/perceptions, $\leq$ 32 points was considered as neutral attitudes/ perceptions, and a score of $\leq 48$ points was considered as positive attitudes/perceptions.

\section{Compliance with ethical standards}

Approval for conducting the research was obtained from the Panimalar Medical College Hospital \& Research Institute IRB (Panimalar Medical College Hospital \& Research Institute IRB \#1/2020/008) data collected from the study participants.

Table 1. Demographic information of health care professionals $(n=262)$

\begin{tabular}{|c|c|c|c|}
\hline Variables & Category & Number & Percentage(\%) \\
\hline \multirow[t]{2}{*}{ Gender } & Female & 204 & 77.9 \\
\hline & Male & 58 & 22.1 \\
\hline \multirow[t]{5}{*}{ Profession } & Medicine & 12 & 4.6 \\
\hline & Dentistry & 4 & 1.5 \\
\hline & Nursing & 231 & 88.2 \\
\hline & Allied Health Science & 9 & 3.4 \\
\hline & Pharmacy & 6 & 2.3 \\
\hline Educational & Diploma & 67 & 25.6 \\
\hline \multirow[t]{3}{*}{ Qualification } & Undergraduate & 124 & 47.3 \\
\hline & Post Graduate & 67 & 25.6 \\
\hline & Doctorate & 4 & 1.5 \\
\hline Professional & Less than 6 months & 64 & 24.4 \\
\hline \multirow[t]{4}{*}{ Experience } & More than 6 months to 2 years & 57 & 21.8 \\
\hline & More than 2 to 6 years of & 83 & 31.7 \\
\hline & More than 6 to 10 years & 16 & 6.1 \\
\hline & More than 10 years & 42 & 16 \\
\hline \multirow{6}{*}{$\begin{array}{l}\text { Specification of } \\
\text { working area }\end{array}$} & High- risk area (ICU,NICU,ER,OT) & 120 & 45.8 \\
\hline & Post-Operative wards & 26 & 9.9 \\
\hline & General wards & 96 & 36.6 \\
\hline & Central Clinical Laboratories & 5 & 1.9 \\
\hline & Blood bank & 5 & 1.9 \\
\hline & BMW Unit & 10 & 3.8 \\
\hline \multirow{6}{*}{$\begin{array}{l}\text { Followed hand } \\
\text { hygiene guidelines } \\
\text { Received education } \\
\text { on HAl within last year } \\
\text { Infection control } \\
\text { department in } \\
\text { your institution }\end{array}$} & Yes & 258 & 98.5 \\
\hline & No & 4 & 1.5 \\
\hline & Yes & 228 & 87 \\
\hline & No & 34 & 13 \\
\hline & Yes & 254 & 96.9 \\
\hline & No & 8 & 3.1 \\
\hline
\end{tabular}




\section{RESULTS}

Demographic information of healthcare professionals

In the present study a total of 367 health care professionals participated, out of which the response rate obtained was $71.4 \%$ (262). In respect of gender majority of them were female 204 $(78 \%)$, in profession majority of them from nursing $231(88 \%)$, in educational qualification most of them were undergraduate 124 (47\%), regarding professional experience most of them have more than 6-10 years of experience, regarding the specification of the working area most of them are working in high- risk area (ICU,NICU,ER,OT) table 1.

About the knowledge of the health care professionals majority of them (93\%) has sufficient knowledge of HAI. 94\% knew that respiratory tract infections are the major cause for HAI and also, they knew that in-patients are the most

Table 2. Health care professional's knowledge regarding the prevention of Hospital-Acquired Infections $(n=262)$

\begin{tabular}{|c|c|c|}
\hline \multirow[t]{2}{*}{ Questions } & \multicolumn{2}{|c|}{ TOTAL } \\
\hline & Yes (\%) & No $(\%)$ \\
\hline Sufficient knowledge on Hospital-acquired infection (HAI) & $243(92.7)$ & $19(7.3)$ \\
\hline Respiratory tract infections (RTI) are the major cause of HAI? & $245(93.5)$ & $17(6.5)$ \\
\hline Inpatients are the most susceptible population to HAI? & $246(93.9)$ & $16(6.1)$ \\
\hline The most important reservoir for acquiring $\mathrm{HAl}$ is health care professionals? & $239(91.2)$ & $23(8.8)$ \\
\hline $\begin{array}{l}\text { You must take sick leave when you are having Respiratory symptoms or GI } \\
\text { symptoms to prevent patients from getting the infection from you? }\end{array}$ & $229(87.4)$ & $33(12.6)$ \\
\hline Acquiring or transmitting infections can be prevented by wearing a glove? & $196(74.8)$ & $66(25.2)$ \\
\hline $\begin{array}{l}\text { Washing hands with soap and antiseptic solutions can decrease the risk of } \\
\text { Hospital-acquired pathogens transmission? }\end{array}$ & $253(96.6)$ & $9(3.4)$ \\
\hline In the case of blood and body fluid exposure is anticipated, gloves must be used & $237(90.5)$ & $25(9.5)$ \\
\hline Two or more patients can be examined without changing the worn gloves & $82(31.3)$ & $180(68.7)$ \\
\hline $\begin{array}{l}\text { Washing hands are unnecessary, if hands are looking clean before examining a } \\
\text { patient }\end{array}$ & $111(42.4)$ & 151(57.6) \\
\hline Consider all patients as potentially contagious? & $202(77.1)$ & $60(22.9)$ \\
\hline $\begin{array}{l}\text { Pathogens are transmitted from one patient to other through hospital staffs due } \\
\text { to inadequate hand washing. }\end{array}$ & $233(88.9)$ & 29 (11.1) \\
\hline $\begin{array}{l}\text { Masks to be provided to the patients with a cough during transfer/transport } \\
\text { out of room for other investigations? }\end{array}$ & $239(91.2)$ & $23(8.8)$ \\
\hline $\begin{array}{l}\text { Having experience in handling splash exposure of the patient's blood, vomit, or } \\
\text { other body fluids? }\end{array}$ & $213(81.3)$ & $49(18.7)$ \\
\hline $\begin{array}{l}\text { The protocol that must be followed immediately after exposure to body fluid of } \\
\text { seropositive cases? }\end{array}$ & $235(89.7)$ & $27(10.3)$ \\
\hline $\begin{array}{l}\text { Daily used items like pen, mobile phone, apron, uniform acts as a carrier for } \\
\text { hospital-acquired infections? }\end{array}$ & $237(90.5)$ & $25(9.5)$ \\
\hline Do you wash your duty uniform or apron daily? & $241(92.0)$ & $21(8.0)$ \\
\hline $\begin{array}{l}\text { Do you clean your stethoscope after examining each patient with an antiseptic } \\
\text { (e.g.70\% alcohol)? }\end{array}$ & $211(80.5)$ & $51(19.5)$ \\
\hline $\begin{array}{l}\text { Will you take off your stethoscope and apron while going to the canteen inside the } \\
\text { hospital after finishing your daily ward rounds? }\end{array}$ & $179(68.3)$ & $83(31.7)$ \\
\hline $\begin{array}{l}\text { There must be proper spacing ( } 1.5 \text { meters) between beds with a curtain between } \\
\text { beds for infected/colonized patients in the ward? }\end{array}$ & $241(92.0)$ & $21(8.0)$ \\
\hline $\begin{array}{l}\text { OT culture and air sampling methods are done to monitor the presence or spreading } \\
\text { of nosocomial infections within the hospital set up }\end{array}$ & $242(92.4)$ & $20(7.6)$ \\
\hline $\begin{array}{l}\text { Infectious agents transmitted between patients by visitors may have negative } \\
\text { impacts on patient outcomes? }\end{array}$ & $229(87.4)$ & 33 (12.6) \\
\hline $\begin{array}{l}\text { Frequent hand washing and avoidance of touching mouth and nose can effectively } \\
\text { protect you, also prevents spreading of infectious microorganism during this } \\
\text { outbreak seasons. }\end{array}$ & $248(94.7)$ & $14(5.3)$ \\
\hline
\end{tabular}


susceptible population to HAI. $91 \%$ agreed that health care workers are the main source of HAI. $87 \%$ of them knew that sick leave to be availed if they have infected with respiratory symptoms or gastrointestinal symptoms. $75 \%$ know that wearing gloves will prevent transmission of infection. 97\% felt that the transmission of $\mathrm{HAl}$ can be reduced by washing hands with antiseptic. $67 \%$ of them accepted that the gloves must be changed while delivering health care to multiple patients. $42 \%$ (111 out of 262 ) felt that no need of washing hands before patient contact. 77\% (202 out of 262) considered all patients as potentially contagious. $91 \%$ (239 out of 262 ) knew that masks to be provided to the patients with a cough during transfer out of room for other investigations. 81\% (213 out of 262) experienced splash exposure of the patient's blood, vomit or other body fluids. 90\% (235 out of 262) knew about the protocol for exposure to body fluid of seropositive cases. $91 \%$ (237 out of 262) were aware that daily used items like pen, mobile phone, apron, uniform acts as a carrier for hospital-acquired infections. 92 (241 out of 262) agreed that washing duty uniform or apron daily is mandatory. $81 \%$ (211 out of 262 ) stated yes for cleaning the stethoscope after examining each patient with an antiseptic (e.g.70\% alcohol). $68 \%$ were (179 out of 262) aware that there must be proper spacing ( 1.5 meters) between beds with a curtain between beds for infected patients in ward. 92\% (241 out of 262) knew that OT culture and air sampling methods are done to monitor the presence or spreading of nosocomial infections within the hospital set up. $87 \%$ (229 out of 262) were aware that the infectious agents can be transmitted to patients by visitors, which may have negative impact on the patient's outcome. 95\% (248 out of 262) knew that frequent hand washing and avoidance of touching mouth and nose can effectively protect them from spreading the infectious microorganism during this outbreak seasons.

In relation to the perception of the health care professional's majority of them i.e 41\% (107 out of 262) strongly agreed that HAI has a negative impact on the patient's outcome. 58\% (153 out of 262) strongly agreed that HAI can be prevented through effective hand hygiene. 53\% (140 out of 262) strongly agreed that improper hand hygiene and improper use of PPE is the reason for hospital- 
Jeyasheelan et al. | J Pure Appl Microbiol | 14(2):1527-1536 | June 2020 | https://doi.org/10.22207/JPAM.14.2.51

Table 4. Health professionals Knowledge \& perception about the prevention of HAI $(n=262)$

\begin{tabular}{llll}
\hline Variables & Levels & Frequency & Percentage (\%) \\
\hline Knowledge on prevention of & Moderately adequate knowledge & 23 & 8.8 \\
hospital-acquired infection & Adequate knowledge & 239 & 91.2 \\
Perception on prevention of & Moderate level of perception & 12 & 4.6 \\
hospital-acquired infection & High level of perception & 250 & 95.4 \\
\hline
\end{tabular}

Table 5. Mean (SD) of the knowledge \& perception of health care professionals $(n=262)$

\begin{tabular}{lllll}
\hline Variables & Mean & $\begin{array}{l}\text { Standard } \\
\text { deviation }\end{array}$ & Minimum & Maximum \\
\hline Knowledge on hospital-acquired infection & 19.58 & 2.70 & 9 & 23 \\
Perception of hospital-acquired infection & 51.97 & 5.62 & 33 & 60 \\
\hline
\end{tabular}

Table 6. Spearman's rho correlation coefficients between knowledge and perception $(n=262)$

\begin{tabular}{llll}
\hline Variables & $\begin{array}{l}\text { Knowledge on hospital- } \\
\text { acquired infection }\end{array}$ & $\begin{array}{l}\text { Perception of hospital- } \\
\text { acquired infection }\end{array}$ \\
\hline Knowledge on hospital-acquired infection & $\mathrm{r}$ & 1 & $\mathrm{P}=0.168^{* *}$ \\
& $\mathrm{p}$ & & $\mathrm{P}=0.006$ \\
Perception of hospital-acquired infection & $\mathrm{r}$ & $\mathrm{P}=0.168^{* *}$ & 1 \\
& $\mathrm{p}$ & $\mathrm{P}=0.006$ & \\
\hline
\end{tabular}

*Significant at the 0.05 level ( 2 tailed)

**Significant at the 0.01 level ( 2 tailed)

acquired infections. $71 \%$ strongly agreed that special precautions to be taken for HBV, HCV, HIV positive patients. $44 \%$ strongly agreed that patients living with HIV Antigen must be treated in an isolation ward. $78 \%$ strongly agreed that vaccination for health care workers is a must. 35\% strongly disagreed that PPE is not needed when a health care worker is vaccinated. $51 \%$ strongly agreed that medical history and antibiotic usage history are important for treating multi-drug resistance microorganisms. $60 \%$ strongly agreed that used needles should not be recapped. $47 \%$ strongly agreed that performing hand hygiene is less likely to transmit infections to patients.

The above table 4 portrays portrays the knowledge and perception of health care Knowledge and perception of health care professionals regarding the prevention of HAls: Adequate knowledge was seen in $91 \%$ of the study participants. $95 \%$ of them had a high level of perception and $5 \%$ of them had a moderate level of perception.
This present study participant's level of knowledge on the prevention of HAI was $19.6 \pm$ 2.7. The level of perception of the prevention of HAl was $52 \pm 5.6$ with a lowest being 33 and the highest being 60 .

Table 6 showed positive fair correlation between the level of knowledge and perception score on prevention of HAl with the r-value of 1 at $P=0.006$.

Below table 7 described the association of knowledge with the selected demographic variables, were significant at $P=0.001$.

\section{DISCUSSION}

Health-care associated infection (HAI) levels have reduced with the development of multifaceted infection prevention and control programs. ${ }^{7}$ Updating the knowledge on current guidelines and protocols on preventing HAI will help the health care professionals to apply them in day to day practices. ${ }^{8}$ 
Table 7. Association between the level of knowledge and demographic variables $(n=262)$

\begin{tabular}{|c|c|c|c|c|}
\hline \multirow[b]{2}{*}{ Variables } & \multirow[b]{2}{*}{ Category } & \multicolumn{2}{|c|}{$\begin{array}{l}\text { Level of knowledge on } \\
\text { hospital-acquired infection }\end{array}$} & \multirow[b]{2}{*}{$\begin{array}{l}\text { Pearson } \\
\text { chi-square } \\
\text { value }\end{array}$} \\
\hline & & $\begin{array}{l}\text { Moderately } \\
\text { adequate } \\
\text { knowledge }\end{array}$ & $\begin{array}{l}\text { Adequate } \\
\text { knowledge }\end{array}$ & \\
\hline \multirow[t]{2}{*}{ Gender } & Female & $17(8.3)$ & $187(91.7 \%)$ & $P=0.633$ \\
\hline & Male & $6(10.3 \%)$ & $52(89.7 \%)$ & \\
\hline \multirow[t]{5}{*}{ Profession } & Medicine & $2(16.7 \%)$ & $10(83.3 \%)$ & $P=0.404$ \\
\hline & Dentistry & 0 & $4(100 \%)$ & \\
\hline & Nursing & $19(8.2 \%)$ & $212(91.8 \%)$ & \\
\hline & Allied Health Science & $2(22.2 \%)$ & $7(77.8 \%)$ & \\
\hline & Pharmacy & 0 & $6(100 \%)$ & \\
\hline \multirow[t]{4}{*}{ Educational Qualification } & Diploma & $5(7.5 \%)$ & $62(92.5 \%)$ & $P=0.858$ \\
\hline & Undergraduate & $11(8.9 \%)$ & $113(91 \%)$ & \\
\hline & Post Graduate & $7(10.4 \%)$ & $60(89.6 \%)$ & \\
\hline & Doctorate & 0 & $4(100 \%)$ & \\
\hline \multirow[t]{5}{*}{ Professional Experience } & Less than 6 months & $8(12.5 \%)$ & $56(87.5 \%)$ & $P=0.467$ \\
\hline & $\begin{array}{l}\text { More than } 6 \text { months to } \\
2 \text { years }\end{array}$ & $5(8.8)$ & $52(91.2 \%)$ & \\
\hline & More than 2 to 6 years & $8(9.6)$ & $75(90.4 \%)$ & \\
\hline & More than 6 to 10 years & 0 & $16(100 \%)$ & \\
\hline & More than 10 years & $2(4.8)$ & $40(95.2 \%)$ & \\
\hline \multirow{6}{*}{$\begin{array}{l}\text { Specification of working } \\
\text { area }\end{array}$} & High-risk area (ICU,NICU, ER,OT) & $9(7.5)$ & $111(92.5 \%)$ & $P=0.206$ \\
\hline & Post-Operative wards & $2(7.7 \%)$ & $24(92.3 \%)$ & \\
\hline & General wards & $8(8.3 \%)$ & $88(91.7 \%)$ & \\
\hline & Central Clinical Laboratories & $1(20 \%)$ & $4(80 \%)$ & \\
\hline & Blood bank & $2(40 \%)$ & $3(60 \%)$ & \\
\hline & BMW Unit & $1(10 \%)$ & $9(90 \%)$ & \\
\hline \multirow{2}{*}{$\begin{array}{l}\text { Have you followed hand } \\
\text { hygiene guidelines? }\end{array}$} & Yes & $20(7.8 \%)$ & $238(92.2 \%)$ & $P=0.000$ \\
\hline & No & $3(75 \%)$ & $1(25 \%)$ & $(\mathrm{S})$ \\
\hline Have you received education & Yes & $16(7 \%)$ & $212(93 \%)$ & $P=0.009$ \\
\hline on HAI within last year? & No & $7(20.6 \%)$ & $27(79.4 \%)$ & $(S)$ \\
\hline Is there an infection control & Yes & $20(7.9 \%)$ & $234(92.1 \%)$ & $P=0.004$ \\
\hline \multicolumn{2}{|c|}{ department in your institution? No } & $3(37.5 \%)$ & $5(62.5 \%)$ & (S) \\
\hline
\end{tabular}

S -significant at the level of 0.01

In this study, $87 \%$ of the participants answered positively about infectious agents transmitted to patients by the visitors may have negative impacts on patient outcomes. $90 \%$ of the participants were aware that daily used items like pen, mobile phone, apron, and uniform will act as a carrier for Hospital-Acquired Infections. Similar level of awareness was revealed in other studies conducted by Khan et al and Haun et al.9,10

The study results revealed that there was adequate knowledge (91\%) on preventing HAls among the participants of this study. Our findings were supported by various other studies which showed that more than $90 \%$ of health care professionals have exquisite knowledge on infection prevention ${ }^{11-13}$. Similarly, the research work of Allah-Bakhshian et al, had above average results about the knowledge of the professionals accessed in his study ${ }^{14}$. The results of the present study was not persistent with the results of the studies conducted to understand the level of knowledge on HAl, which revealed that more than $90 \%$ of the workers had inadequate knowledge about $\mathrm{HAl}^{15-17}$.

Many factors have an impact on the result of the study such as individual characteristics, education, and the number of practical training sessions attended. Researchers reported that 
the training of the healthcare professionals will have a positive impact on healthcare personnel by improving the knowledge and emphasized the need for regular mandatory educational training programs in every health care organization. ${ }^{18}$ Implementation of continuous training programs and knowledge improvement have helped in reducing the incidence of patients progressing with $\mathrm{HAl}^{19}$.

A study conducted in Tamilnadu on using specific indicators for preventing HAI revealed that the infection control intervention should not only involve training and educating the health professionals but also it should address all the other factors like infrastructure, environmental, and personne ${ }^{20}$. The major barriers of preventing HAl must be recognized by the administration. The infection control prevention programs must be supported through adequate personal, financial, and material supplies. Epidemiological surveillance of $\mathrm{HAl}$ is essential to understand the nature and extent of the problem, which also supports the health care workers in treating infections and helps in planning the prevention strategies to deliver a high quality-health care in any of the hospitals ${ }^{20}$. In relation to perception (as per Table-3), the majority of them strongly agreed that HAI has a negative impact on the patient's outcome. $53 \%$ of the participants strongly agreed that improper hand hygiene and improper use of Personal Protective Equipment (PPE) is the reason for hospital-acquired infections. $71 \%$ of the participants strongly agreed that special precautions to be taken for HBV, HCV, HIV positive patients. $78 \%$ of the study subjects strongly agreed that vaccination for health care workers is a must. $51 \%$ of the participants strongly agreed that medical history and antibiotic usage history are important for treating multi-drug resistant microorganisms. $60 \%$ of the participants strongly agreed that used needles should not be recapped. The overall perception mean of this study was $52 \pm 5.6$, which was in line with the findings reported in the public health lieterature ${ }^{21}$. In our present investigation, the level of knowledge and perception on preventing hospital-acquired infections have a strong and positive fair correlation with the r-value of 1 at $P=0.006$. In support of our findings the positive correlation of working experience, the area of working versus the knowledge \& perception of the HAls was documented ${ }^{18,22,23}$.

In the present study, there exists an association between knowledge level versus selected demographic variables such as following protocol of hand hygiene, the training received on HAl within last year, and the presence of an infection control department in their institution at $P=0.001$. This result was similar to a study conducted in Chennai ${ }^{15}$. Out of the 262 study participants, $13 \%$ of health professionals have not undergone education on the prevention of HAls which is in similarity with the observations of the study conducted by Jain et al. ${ }^{24} 91 \%$ of the study participants accepted that health care professionals are the major source for transmission of HAI. However, special priority should be given to interactive educational training that focus on infection control prevention in hospital settings. By conducting a continuous training program, it can be used as an inclusive model for enhancing the knowledge and also will help to resolve the misapprehension towards infectious diseases ${ }^{25}$.

\section{CONCLUSION}

Overall, health care professionals in this study had adequate knowledge and perceptions with respect to the prevention of HAls. Continuous education and vigorous training on HAls will have a positive effect on improving the knowledge and perception at all levels of tertiary care health workers to prevent infections. In order to reduce the HAls, policymakers, and the infection control team must take necessary combined efforts to implement and improve the required interventional strategies. In the future, researchers can consider stronger observational study designs to validate the knowledge, perception, practice, and attitude of the professionals working at the various levels of health care delivery systems, towards the prevention of HAls.

\section{ACKNOWLEDGMENTS}

We are thankful to Dr. S Porchelvan, MSc, MBA, PGDCA, PhD, Professor in Biostatistics for assisting with the statistical analyses.

\section{CONFLICT OF INTEREST}

The authors declare that there is no conflict of interest. 


\section{AUTHORS' CONTRIBUTION}

All authors listed have made a substantial, direct and intellectual contribution to the work, and approved it for publication.

\section{FUNDING}

None.

\section{ETHICS STATEMENT}

This study was carried out in accordance with the recommendations of $\mathrm{NIH}$ guidelines for the Human participants and the protocol was approved by the The Institutional Review Board (IRB) of the Panimalar Medical College Hospital $\&$ Research Institute, Chennai under the protocol number: Panimalar Medical College Hospital \& Research Institute IRB \#1/2020/008. This study conformed to the requirements of the Declaration of Helsinki (as revised in Seoul 2008). All the data collected was kept confidential.

\section{DATA AVAILABILITY}

All data sets generated or analyzed during this study are included in the manuscript and/or the Supplementary Files.

\section{REFERENCES}

1. Viderman D, Khamzina $Y$, Kaligozhin Z, et al. An observational case study of hospital associated infections in a critical care unit in Astana, Kazakhstan. Antimicrob Resist Infect Control. 2018;7(1):57. https:// doi.org/10.1186/s13756-018-0350-0

2. Paudel IS, Ghosh V, Adhikari P. Knowledge, Attitude and Practice of nursing students on Hospital Acquired Infections in Western region of Nepal. Journal of College of Medical Sciences-Nepal. 2016;12(3):103-7. https://doi.org/10.3126/jcmsn.v12i3.16012

3. W.H.O.,Hospital Acquired Infection/definitions.,https:// www.who.int/infection-prevention/publications/ssiguidelines/en/(accessed 05 may 2020).

4. Kabir AA, Akhter F, Sharmin M, et al. Knowledge, Attitude and Practice of Staff nurses on Hospital Acquired Infections in tertiary care Hospital of Dhaka city. Northern International Medical College Journal. 2018;10(1):347-50. https://doi.org/10.3329/nimcj. v10i1.39330

5. Cardo, D, Dennehy, PH, Halverson, P, et al. Moving toward elimination of healthcare-associated infections: a call to action. Am J Infect Control. 2010;38(9):671675. https://doi.org/10.1016/j.ajic.2010.09.001

6. Ghanbari MK, Farazi AA, Shamsi M, Khorsandi M, Esharti B. Measurement of the health belief model (HBM) in nurses hand hygiene among the hospitals. World Appl Sci J. 2014;31(5):811-8.

7. Dick AW, Perencevich EN, Pogorzelska-Maziarz
M, Zwanziger J, Larson EL, Stone PW. A decade of investment in infection prevention: a cost-effectiveness analysis. Am J Infect Control. 2015;43(1):4-9. https:// doi.org/10.1016/j.ajic.2014.07.014

8. Kalantarzadeh M, Mohammadnejad E, Ehsani SR, Tamizi Z. Knowledge and practice of nurses about the control and prevention of nosocomial infections in emergency departments. Archives of Clinical Infectious Diseases. 2014;9(4). https://doi. org/10.5812/archcid.18278

9. Khan HA, Baig FK, Mehboob R. Nosocomial infections: Epidemiology, prevention, control and surveillance. Asian Pac J Trop Biomed. 2017;7(5):478-82. https:// doi.org/10.1016/j.apjtb.2017.01.019

10. Haun N, Hooper-Lane C, Safdar N. Healthcare personnel attire and devices as fomites: a systematic review. Infect Control Hosp Epidemiol. 2016;37(11):1367-73. https://doi.org/10.1017/ice.2016.192

11. Nag K, Datta A, Karmakar N, Chakraborty T. Knowledge, attitude and practice about hospital acquired infection among health care personnel in a tertiary care hospital of Tripura. International Journal of Research in Medical Sciences. 2018;6(10):3303-3308. https:// doi.org/10.18203/2320-6012.ijrms20184037

12. Sodhi K, Shrivastava A, Arya M, Kumar M. Knowledge of infection control practices among intensive care nurses in a tertiary care hospital. Journal of Infection and Public Health. 2013;6:269-275.https://doi. org/10.1016/j.jiph.2013.02.004

13. Chan R, Molassiotis A, Eunice C, et al. Nurses' knowledge of and compliance with universal precautions in an acute care hospital. Int J Nurs Stud. 2002;39:157-163. https://doi.org/10.1016/S00207489(01)00021-9

14. Allah-Bakhshian A, Moghaddasian S, Zamanzadeh V, Parvan K, Allah-bakhshian M. Knowledge, attitude, and practice of ICU nurses about nosocomial infections control in teaching hospitals of Tabriz. Iran Journal of Nursing. 2010;23:17-28.

15. Vinodhini K, Devi AB. Study on Infection Control Pratices Among Health Care Workers in a Speciality Hospital, Chennai. Pollution Research. 2016;35(3):5512.

16. Luo Y, He G-P, Zhou J-W, Luo Y. Factors impacting compliance with standard precautions in nursing, China. Int J Infect Dis. 2010;14. https://doi. org/10.1016/j.ijid.2009.03.037

17. Daniela D' Alessandro, Antonella Agodi, Francesco Auxilia, Silvio Brusaferro, Laura Calliga. Prevention of healthcare associated infections: Medical and nursing students' knowledge in Italy. Nurse Education Today, 2014;34(2):191-195. https://doi.org/10.1016/j. nedt.2013.05.005

18. Suchitra J. Impact of education on knowledge, attitudes and practices among various categories of health care workers on nosocomial infections. Indian Journal of Medical Microbiology. 2007;25:181.http://dx.doi. org/10.4103/0255-0857.34757.

19. Askarian M, Honarvar B, Tabatabaee H-R, Assadian O. Knowledge, practice and attitude towards standard isolation precautions in Iranian medical students. J Hosp Infect. 2004;58:292-296.http://dx.doi. 
org/10.1016/j.jhin.2004.07.004

20. Usha Krishnan K. A study on assessment of challenges and effectiveness of infection control measures in a tertiary care hospital using specific infection control indicators., 2018. Doctoral dissertation, Madras Medical College, Chennai. Accessible at www. tnmgrmu.ac.in.

21. Tamrat Befekadu Abebe, Akshaya Srikanth Bhagavathula,Yonas Getaye Tefera, Healthcare professionals' awareness, knowledge, attitudes, perceptions and beliefs about Ebola at Gondar University Hospital, Northwest Ethiopia: a crosssectional study. J Public Health Afr. 2016;7:570. https:// doi.org/10.4081/jphia.2016.570

22. Mythri H, Arun A, Kashinath KR. Perception and Practice Regarding Infection Control Measures among Healthcare Workers in District Government Hospital of Tumkur, India. Indian J Public Health Res Dev. 2016;7(1):127-32. https://doi.org/10.5958/09765506.2016.00025.5

23. Choi JS, Kim KM. Factors influencing the self-perceived practice levels of professional standard competency among infection control nurses in Korea. Am J Infect Control. 2014;42(9):980-4. https://doi.org/10.1016/j. ajic.2014.05.023

24. Jain A, Mandelia C, Jayaram S. Perception and practice regarding infection control measures amongst healthcare workers in district government hospitals of Mangalore, India. International Journal of Health \& Allied Sciences. 2012;1(2):68-73. https://doi. org/10.4103/2278-344X.101668

25. Horn WA, Larson EL, McGinley KJ, Leyden JJ. Microbial flora on the hands of health care personnel: differences in composition and antibacterial resistance. Infect Control Hosp Epidemiol. 1988;9(5):189-93. https:// doi.org/10.1086/645831

26. Liu X, Zou N, Zhu D, Wang D. Influencing factors analysis and modeling of hospital-acquired infection in elderly patients. Journal of Combinatorial Optimization. 2019;37(1):248-70. https://doi.org/10.1007/s10878017-0222-1 